\title{
The Impact of Covid-19 Pandemic Towards Sustainability of the Social Environment in Banjarmasin
}

\author{
Ahmad Nadi ${ }^{1}$ Akhmad Firdaus ${ }^{1 *}$ Anita Noviana ${ }^{1}$ Yustinus Kus Sukma Aji ${ }^{1}$ \\ ${ }^{1}$ Master of Social Science Education, Postgraduate Program, Lambung Mangkurat University, Banjarmasin, Indonesia \\ ${ }^{*}$ Corresponding author. Email: firdausakhmad021@gmail.com
}

\begin{abstract}
Status of a pandemic and a national disaster is a sign that Covid-19 has a significant impact on various aspects of people's lives. Currently, it has been changed social environment in Banjarmasin. This study highlights the social impacts that occurred in Banjarmasin during pandemic and predicts the condition after the pandemic. The visible impact is that some social traditions in Banjarmasin are no longer exist and there are concerns about their sustainability. This study aims to explain the impact of Covid-19 for sustainability of the social environment in Banjarmasin. The research method used in this scientific article is a simple survey method. The purpose of this survey research is to provide an overview of the impact of the Covid-19 for the sustainability of the social environment and existing social traditions, as well as to predict people's behavior towards the sustainability of these social traditions. The survey data were analyzed by descriptive analysis methods. This method is used to describe the impact of a pandemic as a social phenomenon, which is then explained in a descriptive narrative. Then the results showed that the pandemic had an impact on the ten social traditions of the people in Banjarmasin, there are: 1) Shaking hands; 2) Kiss the hand; 3) Gotong royong; 4) Thanksgiving; 5) Berelaan; 6) Wedding party or Aruh Penganten; 7) Pilgrimage to the Grave; 8) Mewarung; 9) Taklim; and 10) Homecoming.
\end{abstract}

Keywords: Impact, covid-19 pandemic, social environment.

\section{INTRODUCTION}

Pandemic means an epidemic or disease that is contagious everywhere, covering a wide geographic area [1]. The ongoing Covid-19 pandemic is a major threat to public health around the world.

We can understand that the threat of Covid-19 cannot be underestimated. The status of pandemics and national disasters is a sign that this virus has a significant impact on various aspects of our lives. This virus also has the impact of major changes to a crisis that is detrimental to the survival of people in various regions. We can see how changes in technology, economy, politics and socio-cultural life. Change requires us to be prepared, respond with attitudes and actions as well as always learn new things. Indonesia has big challenges in handling Covid-19. Of all the aspects that are currently challenging, the authors concentrate on the aspect of social environmental sustainability as something that is quite rare for researchers to study. The aspect of the social environment in Banjarmasin during the Covid-19 pandemic is the author's concentration in this discussion.

The social environment is a community environment that is closely related to daily life. Purwanto argues that "the social environment is all people or other human beings who influence us ". Humans form social groupings among each other in an effort to sustain life and develop life. In a social life, humans also need an organization, such as schools, community groups and others [2]. According to Muhroji et al, the environment is something that is beyond the limitations of a person's genetic potential and abilities and plays a role in setting up facilities or even inhibiting a person from growing [3]. This opinion is supported by Saragih et al that the social environment is all people or humans who affect the individual either directly or indirectly. It is part of the Environment [4]. It can be concluded that the social environment is an "area" where social interaction takes place between various groups, along with the institutions, symbols, values and norms, and is related to the natural environment and the environment in which human contact takes place.

Society is part of the social environment. Djajadiningrat revealed that every society is a container of culture, which is a system that draws the behavior of all people or members towards a core of the system concerned [5]. Human behavior patterns are based on biological, social and cultural influences. The existence of culture implies a social environment in which humans with their innate potential to behave are encouraged to learn to behave in human ways. Gillin and Gillin [6] explain that society is a group of people who have the same habits, traditions, attitudes, and feelings of unity. This understanding shows that the equality of unity does not stand alone, but was built over a long period of time to form a common view among these community groups. The duration of the formation of the group creates a habit or tradition, then unique attitudes and behavior patterns are built by the community, which differentiates it from other communities. 
The above definition provides us the basis for defining the people in Banjarmasin. Everyone who lives and resides in Banjarmasin can be said to be the people of Banjarmasin. In accordance with the explanation above, that society will form a tradition, even if someone is not from that community when they inhabit an area that already has a tradition that is continuous, then they will follow that tradition to become part of the community and social environment.

Currently, changes have been felt in the social environment of the people in Banjarmasin. This fast and drastic change is caused by Covid-19. According to the theory of social change, disaster is one of the factors causing social change. This can be happened because a disaster in a society will change all forms of structures and living systems that are planned. Many factors lead to changes in the social structure of society. One of them is disaster. According to Fakhrul [7], changes in social behavior caused by disasters can be physical and psychological, such as: 1.) Less kinship and spirit of gotong royong; 2.) The reduction of routine activities carried out by the community before the disaster, such as gotong royong, religious activities, recitation activities, etc; 3 .) There were victims due to disasters which resulted in the reduction of community family members. This has resulted in psychological trauma to the disaster victims. 4.) Most of people lost their jobs so that many people became unemployed. The social environment of people in Banjarmasin often involves a lot of physical contact such as the tradition of shaking hands, kissing hands of people who are respected, smiling and greeting when they meet, mewarung, and others. This factor is predicted to have contribution in increasing Covid-19 cases in this city. Covid-19 has two types of transmission. The first is from splashing the saliva of an infected person, which requires people to keep a distance from each other. Then the second type of transmission from the surface of the object where the virus is located. Hence, people are asked not to touch their face, eyes, nose, or mouth when they are in public spaces. The government has responded to the rapid spread of Covid-19 by a Large-Scale Social Restriction (PSBB) policy. Large-Scale Social Restriction is restriction on certain activities of residents in an area suspected of being infected with Covid-19 in such a way as to prevent the possible spread of Covid-I9. According to the regulations stipulated in the Minister of Health Regulation (Permenkes) Number 9 of 2020 which regulates the PSBB Guidelines, it states limiting all certain activities, such as: school and workplace holidays; restrictions on religious activities; restrictions on activities in public places or facilities; restrictions on social and cultural activities; restrictions on transportation modes; and restrictions on other activities specifically related to defense and security aspects. The limitation of certain activities in question is to limit the gathering of people in large numbers at a certain location. The activities referred to include school, office and factory work, religion, meetings, wedding parties, recreation, entertainment, festivals, sports competitions and other gathering activities that use public or private facilities. The case of Covid-19 transmission has not shown a decline in Banjarmasin, but PSBB was discontinued, and was followed by an announcement by President Joko Widodo on May 15 to immediately implement a 'new normal' to boost economic growth. The 'new normal' policy allows people to enter offices, allow people to travel, and open shopping centers as long as follow health protocols. This strategy means that the government relies on the community to prevent the spread of Covid-19 and tends to place individuals as bearers of responsibility. Public awareness is the key to this new normal phase.

Since the initial phase of the spread, followed by the implementation of the PSBB, to the announcement of a new normal phase in Indonesia, Covid-19 has had a major impact on political, economic, social, cultural, defense and security aspects, as well as the welfare of the people in Indonesia. The author highlights the social impacts that have occurred in Banjarmasin, both in the current phase of the spread of Covid-19 until Covid-19 solution has been found. The most obvious impact is that some social traditions of the community are no longer exist and there are concerns about their sustainability. In addition, Covid-19 psychologically has an impact on the loss of people's sense of security in their social environment. Therefore, this research aims to explain the impact of the Covid-19 pandemic for the sustainability of the social environment of the people in Banjarmasin.

\section{METHODS}

The research method used in this scientific article is a simple survey method. According to Sugiyono, the definition of the survey method is research conducted using a questionnaire as a research tool carried out on large and small populations, but the data studied is data from samples taken from that population, so that relative incidence, distribution, and relationships between variables, sociology and psychological are found [8].

The purpose of survey research is to provide a detailed description of the background, features, and characteristics of a case or event of a general nature. The analytical method used is descriptive analysis to measure several social phenomenon, which are then explained descriptively or narrative. According to Sugiyono [8] what is meant by descriptive analysis method is a statistical method used to analyze data by describing the data that has been collected as it is without intending to make generalized conclusions or generalizations.

The survey was conducted on research subjects, which is represented by 100 respondents consisting of 33 men and 67 women from various types of work. Respondents were randomly selected to fill out a questionnaire which aimed to reveal data about the sociological and psychological impacts of the Covid-19 pandemic. Survey questions are shared online via google form media and carried out from 11 to 12 July 2020.

From the survey data, a general description of the phenomenon and impact of the Covid-19 pandemic on the social environment of people in Banjarmasin during the pandemic and later on a Covid-19 solution has been found. Therefore, this study also aims to predict the trends and behavior of the people in Banjarmasin when the pandemic 
status has ended. The survey data are then analyzed descriptively and narrative, so that a pattern or conclusion can be drawn regarding the impact of the Covid-19 pandemic on the sustainability of the social environment of the people in Banjarmasin.

\section{RESULTS AND DISCUSSION}

The authors have identified the Banjarese cultural traditions that were often carried out by the people in Banjarmasin before the Covid-19 has been found, especially those related to the social environment and involving physical contact. The implementation of this tradition can be used as an indicator of a sustainable social environment for people in Banjarmasin. Various traditions are as follows:

1. Shaking hands when meeting and saying goodbye

2. Kissing the hands of people who respected

3. Gotong Royong

4. Thanksgiving

5. Bermaafan/berelaan while bershalawat after finishing prayers and celebration

6. Wedding Party or "Aruh Penganten"

7. Pilgrimage to the graves of scholars and families

8. Mewarung

9. Assembling Taklim

10. Homecoming

Those are the ten traditions of the people in Banjarmasin that the authors identify related to the social environment and involve physical contact.

The ongoing Covid-19 pandemic is predicted to have a direct impact on the sustainability of social traditions in Banjarmasin. How much impact will it have and how will this tradition be sustainable during a pandemic or later when the pandemic has been ended. This impact can be described after collecting data on some of the people of Banjarmasin who were selected as samples.

Data obtained through questions asked by conducting a simple survey in the form of questions about the behavior of the people in Banjarmasin regarding their social environment. The survey method was simplified by only including two response options, yes and no. The survey was carried out after the announcement of the "new normal" phase by the government, which means that there are no more binding rules or sanctions related to protocols or public behavior during the Covid-19 pandemic emergency. This means that the prevention of transmission and the risk of spreading Covid-19 really depend on the awareness of each individual in society. Thus, the survey results and data obtained are as follows:

\subsection{Shifting Traditions of the People in Banjarmasin during the Covid-19 pandemic}

The survey was started with a question which aims to determine the level of awareness of the people in Banjarmasin towards implementing health protocols during the Covid-19 pandemic. In our opening question, we asked the public whether Covid-19 had an effect on their lives. As a result, the Covid-19 pandemic affects almost all people's lives, including the social environment. This is proven by $98 \%$ of the public choosing the answer to Covid-19 to affect their social life. However, it turns out that there are also people who have not felt the impact of the pandemic, even though the figure is very small, which is $2 \%$ or two out of a hundred people. Likewise, the question regarding the application of health protocols shows the same number, the majority of them admit to applying health protocols in general, and only $2 \%$ who admit they do not.

Examining our health protocol then outlined the questions in more detail, such as regarding the use of masks, physical distancing, and hand washing habits. The result was that $99 \%$ of the people answered that they used masks when they left the house and $1 \%$ answered no. In the physical distancing survey, $97 \%$ of respondents admitted that they maintained physical distancing when in public spaces and $3 \%$ of them answered viceversa. Washing hands as selfprotection for people during a pandemic has a $100 \%$ response that they wash their hands before and after doing something.

The survey results showed that there are still some people who do not implement health protocols such as not wearing masks and not maintaining physical distance. This is consistent with the reality we see in society. We can see it in several public spaces such as roads, markets, and so on. Community behavior is difficult to control without strict rules or sanctions. Behavior that is not aware of the dangers of spreading Covid-19 can be seen when there are still a few people queuing without maintaining physical distance, using masks but with inappropriate use (just hooking them to the chin, neck, or ears). In the data, $2 \%$ of the community admitted that they did not implement general health protocols. This could be one of the reasons for the continued increase in positive cases of Covid-19 in Banjarmasin.

It is very difficult for the whole community to be able to implement health protocols. Health protocols that are no longer regulated by law and are only used as recommendations will only become false social rules. Some people enforce it and some don't. This is in accordance with the theory of obedience according to Harre and Secord [9] to social rules, that a rule will only be obeyed if there is a desire for order, intrinsic sanctions, or realizing his role and identity in society.

Unlike other health protocols such as maintaining physical distance and wearing masks, washing hands has different responses from the people in Banjarmasin. From a survey conducted, all respondents admitted that they washed their hands before and after doing something during the pandemic. This is a positive trend for people's behavior towards cleanliness. This is an indicator that public awareness of personal hygiene and health has increased significantly during a pandemic. Hopefully this good habit will continue even until the pandemic ends.

The impact of the Covid-19 pandemic on the sustainability of the social environment of the people in Banjarmasin City, which is the main subject of discussion, can be seen from the survey questions specifically related to ten Banjarese cultural traditions that involve physical contact.

1. Shaking hands when meeting and saying goodbye. 
In this tradition, $93 \%$ of people don't do it anymore during a pandemic and only $7 \%$ of people do it. According to Suriansyah Ideham in his book Urang Banjar and his Culture [10], shaking hands is a very popular tradition for people in Banjarmasin, even Indonesia in general. Shaking hands and kissing the hands of elders is part of the customs and social ethics for them.

The Banjarese community has even introduced the tradition of shaking hands as early as possible. When the child is approaching two years old, the mother usually teaches how the child shakes hands with other people. By practicing it with the child like shaking his hand and then kissing it, then after being given it repeatedly the child will be able to imitate it.

Planting which from an early age has made this tradition so strong in the people of Banjarmasin, apart from that shaking hands and kissing hands are also considered to have ethical values which if not implemented will be considered arrogant, sometimes lazy or impolite and will receive reproach from other communities. So even though it has been determined as something that is forbidden to do during a pandemic, there are still quite a few people who do it.

2. Kissing the hand of a respected person

Then the habit of kissing the hand of a respected person was also only practiced by $24 \%$, and $76 \%$ did not. This means that the habit of kissing parents' hands is more difficult to break than the tradition of shaking hands. As has been explained in the analysis of the shaking tradition above, kissing hands is also rooted in the same tradition and has even deeper meaning as respect and obedience.

3. Gotong Royong

According to KBBI, Gotong Royong is an activity that makes you work together with other people in order to get the same goal and help each other. As many as $86 \%$ of respondents admitted that they no longer practiced gotong royong during the pandemic and only $14 \%$ of respondents continued to do so.

There are still people who continue to do gotong royong, it is predicted because gotong royong has long been rooted in the traditions of people in Banjarmasin. In the era of the traditional Banjarese community, gotong royong was very familiar with agricultural activities, such as Balangai Handil, Batabat or making small dams in the dry season, or gotong royong to repel pests of rice fields such as Bahantup Babi or Mahampang Rat. In the next era which is Islamic era, Gotong Royong was increasingly encouraged to build mosques or surau, and community service commemorating religious holidays [10]. Therefore, in the modern era, gotong royong is still sustainable but the goals are increasingly complex. Especially with regard to the environment, currently it is very difficult for people in Banjarmasin to do it alone without gotong royong.

4. Thanksgiving/Selamatan

The survey results stated that $93 \%$ of the community would not carry out the thanksgiving, while $7 \%$ still chose to do it. Then, if they are positioned as invited guests at the thanksgiving event, $79 \%$ of the people choose not to attend, and $21 \%$ will still attend.

Observing the high number of voters for the thanksgiving practitioners and attendance at the pandemic, we need to look at the cultural foundations of the Banjarese in general. As explained by the Culturalist and Banjarese scholar Alfani Daud [11], in the past, most ceremonial activities or now called Selamatan for the Banjarese were carried out at the stages of a person's life. Various events of selamatan are a continuation of old habits, including those customary after Islam developed, carried out for fear of sanctions from their ancestors. In addition, it is also believed to be good for the person concerned to strengthen his enthusiasm, simulate an abundant fortune for him in the future, as an effort to avoid danger, and as a blessing activity.

5. Bermaafan/berelaan while bershalawat after completion of prayer and celebration

It still related to selamatan, following tradition is berelaan while bershalawat after finishing prayer together or celebration. It also willing to do a handshake at the same time. The people who choose not to volunteer anymore are as much as $91 \%$ and the remaining $9 \%$ still do it.

From a historical point of view, the tradition of berelaan while praying may have started when the Banjarese Sultanate was in the era of Sultan Adam who issued a law so that the village chiefs built langgar in their respective villages and spearheaded performing friendly prayers in these langgar-langgar. Then in the mosques the habit developed after performing Friday prayers, which is performing wirid and prayers, then all the attendees stood and read the prayers together, trying to shake hands with each other, especially many who tried to shake the hands of the scholars. This tradition is suistained by the Banjarese in the village up to the capital city. In its development, shaking hands and praying are done not only after praying but when dissolving an event or celebration while saying the word "belelaan" [12], [13].

According to Anwarul Haq, shaking hands and to people who are very close can also be followed by hugging is a sign of Banjarese hospitality and signifies a heart full of compassion, which a Muslim has for his fellow Muslims and this will eliminate the disease in their heart to each other, while saying berelaan which means to forgive each other [13]. In the other hand, shalawat is defined as the hope of mercy and glory. Salawat of the believers (human and jinn) is a request for mercy and glory to Allah for the Prophet, like Allahumma salli 'ala sayyidina Muhammad [13].

It seems that the tradition of breathing religion will be very difficult to abandon the people in Banjarmasin even though it is being hit by a pandemic.

6. Wedding party or "Aruh Penganten"

In the larger tradition of thanksgiving, which is wedding receptions, $86 \%$ of the people answered that they would not hold a wedding party during the pandemic and $14 \%$ of the people chose to continue. The question was then developed if the community was positioned as an invitee at the wedding party, then $82 \%$ of them chose not to attend and the remaining $18 \%$ chose to remain.

We can understand the choice of respondents' answers that show different numbers in the tradition of thanksgiving and wedding party. First, in the implementation of the event, only $7 \%$ of respondents chose to keep doing it, while at wedding party the figure was higher, which is $14 \%$. Why is 
that? We all know that marriage is a big celebration and a special moment for people in Banjarmasin, besides that the religious advice to broadcast marriage is also categorized as the reason for the difference in the number of respondents. Second, in the question, if the respondent is positioned as an invited guest, the difference is also seen, which that voter respondents who still attend the thanksgiving event have $2 \%$ more differences than the party. The reason is that there will be far more invited guests at wedding party than thanksgiving, so this affects the psychological condition of the invitees and the potential for fear of a greater risk of Covid-19 transmission. Therefore, there were fewer voters at the wedding party.

From a historical perspective, why do Banjarese still hold or attend wedding party invitations is understandable. In order to marry a woman from Banjar performing aruh, where the element of inviting or gathering close relatives is contained in it and there is a rice dish with its side dishes, after Islam enters this tradition it is reinterpreted or modified with the addition of Islamic elements such as reciting a prayer of congratulations. The element of taking blessings is prominent in this activity. [14] As well as being rooted in previous cultures, the religious suggestion to broadcast marriage also strengthens the community to continue to carry out wedding party.

7. Pilgrimage to the graves of scholars and families Turning to the tradition of pilgrimage to the graves, respondents chose to continue doing the grave pilgrimage during the pandemic many as $27 \%$ of, while the remaining $73 \%$ did not. This is because the tradition of the grave pilgrimage is usually carried out by the Banjarese community on certain days, especially religious anniversary days. This condition causes the community to come to the funeral relatively at the same time, causing a crowd and a large gathering of people. Of course this raises fears of the risk of transmitting Covid-19.

Surveys show a high number of grave pilgrims during the pandemic. This is understandable because the Banjarese community has developed an understanding of scholars and their karamah. Again we quote the opinion of Alfani Daud in his book Islam and Banjar Society [11], for the Banjarese community, a wali is a sacred human, a holy person, whose grave is the target of pilgrimage and negligence to carry out the "obligatory" pilgrimage because it has been adultery or because of habit can cause health problems for a resident. The grave of the wali becomes the target of pilgrimage to make vows for the pilgrimage when something has been fulfilled. In other words, the wali has the ability to become an intermediary so that a prayer or wish is approved by Allah. Then, in addition to visiting the wali's grave, the Banjar community also develops the belief that reciting the Qur'an besides the grave will prevent the deceased from being tormented by angels, therefore some people still make pilgrimages to their family graves.

8. Mewarung

We do not only concern in mewarung activity but also concern in more modern phase like hanging out in cafes. As many as $88 \%$ of respondents admitted that they no longer did it during the pandemic, while $12 \%$ continued to practice mewarung. There are some people who find it difficult to leave this tradition, especially in the new normal era which no longer binds people to just being at home.

For some people, mewarung are a way to be happy and happy to increase their immunity, which can be linked to health conditions and defense against the Covid-19 virus. More about the origin of culture, mewarung tradition is included in the economic tradition of the Banjarese. The root of this tradition is the village residents whose livelihoods are traders, they usually provide breakfast for other people who are farming and gardening. It is not surprising that the warung is a place to rest for some people before and after work. A lot of communication is established at the shop.

The oral communication tradition in the Banjarese community is felt to be more dominant than the written tradition. This can be found in the habit of Banjarese who likes to talk, bapandiran in shop, on the banks of the river when doing social activities, in Muhara Lawang with neighbors next to the house (which are located side by side), in the market or in a crowd location (crowd), even during activities. Recitation is often carried out without realizing it. This oral tradition in the study of communication is considered an effort to familiarize oneself with others in terms of communication, namely phatic communications [14].

9. Assembling Taklim

People in Banjarmasin are known for being religious and upholding the value of religiosity. It turns out that the number of voters who no longer attend majelis taklim during the pandemic is quite high at $91 \%$, while $9 \%$ still choose to attend. This was influenced by the decision of the scholars to choose to become pioneers to help educate the public to follow protocols health during the pandemic.

As an analysis for the $9 \%$ of respondents who chose to continue attending recitation, it seems that we need to examine the roots of the religious culture of the Banjarese. The recitation activity has strong roots in the Banjarese community. The first recitation started by a Banjarese scholar, Syekh Arsyad who opened recitation in Dalam Pagar around the last two or three decades of the 18th century, finally various villages in ancient times became the orientation of the recitation for the surrounding villages or even wider areas. These villages have one or more scholars who provide religious instruction to the lay community around them or to prospective scholars who come from distant villages. The scholars as well as the students of their recitation who have returned from the recitation will also give religious lessons to lay people in their respective villages. Finally, each village had a figure who gave religious lessons, so that the local people were excited to follow him. Among the Banjarese community there is a growing belief that if there are 40 people in a Taklim they must be considered holy people. Saleh people are described as people who are obedient in worship and their way of worship is right, so they are close to Allah, and their prayers tend to be granted by Allah. Directly and indirectly, these recitations have shaped the religious behavior of the Banjar people for a long time. [13]

In Banjarmasin, attending taklim or recitation is a necessity for people who are thirsty for spiritual advice and 
inspiration. Attending an taklim is also a means to entertain yourself from work routines, this is because by attending a taklim, you will feel happy when traveling from home to the taklim place, then you can interact and stay in touch with other people, entertainment is also felt when the recitation material is interspersed with jokes, plus with the atmosphere around the recitation place filled with various snacks. For the Banjar people attending recitation also has its own prestige value, because people who understand religious knowledge are usually more respected in society. Apart from being rooted in its history, this is what makes the tradition of recitation difficult to abandon even during the pandemic.

10. Homecoming

As many as $82 \%$ of respondents admitted that they did not go home on holiday, while $12 \%$ still did. The Eid homecoming for the Banjarese community is an annual worship or ritual which cannot be violated and it can be said that it does not recognize socio-economic status. So, this annual ritual is always rife and may violate any rules and obstacles if the desire to go home for Eid has become a top priority when facing Eid al-Fitr.

Culturally, the Eid homecoming activity is identical to the victory that Muslims get after one month of fasting; so that one manifestation of this victory must and will be commemorated with the family in their hometown.

According to the migration theory, this spontaneous and temporary migration can be categorized as "temporary migration" because every migrant only intends to travel or move from their place to another place for a relatively short time without the intention to settle [15]. In the implementation of spontaneous and temporary migration, there are no heavy burdens in terms of the economic magnitude or costs incurred, because the goal is happiness and joy to be able to gather with family. The joy that will be enjoyed with families who are far from the residence of the migrant erases all social and economic burdens borne by travelers. They do not care about the many risks such as pandemic diseases or the costs incurred.

Furthermore, according to Kuntowijoyo [16], although it is not specific to the Banjarese community. Hermeneutically, homecoming is a process of returning oneself to peace of mind, peace in practice, and concern for poverty. Modernity, of course, will give birth to self-isolation, as a result of capitalism, where workers face impersonal giants in urban environments. Powerlessness, feelings of isolation, and meaninglessness tend to come upon the souls of modern humans when they are in the power of the owners of capital. Not only that, individualism also strengthens because in a city a set of days is a time for work [16]. This means that going home is also done to get away for a moment from urban problems.

\subsection{Prediction of Community Behavior in Banjarmasin after Covid-19 Pandemic Ends}

The predictive survey when the pandemic ends is aimed at identifying people's "New Normal" habits towards the continuity of the implementation of health protocols. The first is about people's behavior towards implementing general health protocols when the pandemic period ends. The result is that only $18 \%$ of respondents said they would continue to apply the Covid-19 emergency health protocol, while the remaining $92 \%$ said they would not apply it again. Then, in order to find out more details about people's behavior regarding the sustainable application of health protocols, survey questions also revolved around the use of masks. As many as $79 \%$ of respondents admitted that they would still use masks even though the pandemic period was over, the remaining $21 \%$ chose not to use them anymore. The new habit during the next pandemic is about maintaining physical distance when in public spaces. 54\% of the people answered that they would continue their habit of maintaining physical distancing when the pandemic ended and $46 \%$ answered that they no longer practiced it. Furthermore, regarding the habit of washing hands, the majority of respondents admitted that they would still wash their hands before and after doing something, as many as $94 \%$ and only $6 \%$ of respondents who answered they did not do it anymore. This shows a positive trend and has become one of the good habits for the community as a result of the pandemic.

Pandemic does not only have a negative impact on environmental sustainability. Behind that, there are good habits that should be maintained. Good habits that are formed after a pandemic such as maintaining personal hygiene by washing hands will increase people's resilience to various health threats in the future. People are also more concerned about cleanliness, so that it has a positive effect on the level of personal health and the environment. The experience of dealing with a pandemic has also made society psychologically better in facing various challenges of the times, including health threats and lifestyle changes as well as increased technological sensitivity.

The core discussion regarding the impact of a pandemic on the sustainability of the social environment of the people IN Banjarmasin is illustrated by the predictive survey results when the pandemic period ends. In the tradition of shaking hands or shaking hands, as many as $72 \%$ of the people will do it again and $28 \%$ of them will no longer do the shaking. Then, the tradition of kissing the hands of people who are respected is also affected, which is only $80 \%$ of respondents who chose the answer still practice the hand kissing tradition. This means that $20 \%$ of respondents chose not to practice this tradition when the pandemic has ended. The implementation of gotong royong tradition in the community has also received the impact of this pandemic. The predictive survey results if the pandemic ends show that $88 \%$ of respondents will continue to carry out gotong royong, while $12 \%$ say they no longer implement it.

The next related tradition is tradition based on religion, which called as berelaan after praying together and when the prayer or thanksgiving is finished. This tradition involves both physical and verbal contact. The survey results show that $80 \%$ of the community will still maintain this tradition when the pandemic ends and $20 \%$ will no longer implement it. Another religious-based tradition is organizing thanksgiving events by inviting a large number of people, the result shows that $83 \%$ chose to still do it and 
$17 \%$ didn't anymore. It still related to thanksgiving, if the respondent is positioned as an invited guest at a thanksgiving event in the aftermath of the pandemic, $91 \%$ of them choose to continue attending and $9 \%$ will not attend. The tradition of thankgiving which can be said to be quite important is the tradition of surviving a big wedding party, respondents answered that $88 \%$ of them would carry out a wedding party if they got married outside of the pandemic. Then, if the respondents were invited to a wedding reception during the pandemic, $92 \%$ said they would attend, while the remaining $8 \%$ said they would not. In the next tradition which is also categorized as involving contact with many people is the grave pilgrimage. If the pandemic period ends, the community responds with $92 \%$ who are asked to answer that they will do this tradition again, and $8 \%$ no longer do it. Then switching to a tradition that is quite popular in traditional and modern societies is the mewarung tradition, which is hanging out in places to eat. The results are quite different from other traditions where survey questions are asked, as $54 \%$ of respondents answered that they no longer do so at the end of the pandemic. This means that only $46 \%$ are still doing mewarung.

A tradition that is also in the spotlight because it is often a religious habit of the people in Banjarmasin City is to directly attend the majelis taklim or shcolar recitation. It turned out that respondents answered that $84 \%$ would return to the taklim when the pandemic ended, and $16 \%$ chose not to attend. Next, a tradition that is quite difficult to leave of people in Banjarmasin is homecoming tradition on major religious holidays. The data shows that $82 \%$ of the people who choose to do the homecoming tradition when the pandemic ends, while $18 \%$ choose not to go hometown. In addition, respondents who chose not to survey questions related to health protocols or implementation of Banjarese cultural traditions relating to the social environment and involving physical contact were inseparable from the habits that had been implanted or implemented during the pandemic. This has become a habit and psychologically inherent in people's lives, so that there is a fear of returning to behaving like before the pandemic. Then, government policies that give rise to a new term in handling the pandemic, called as "new normal" policy which has now even been revised to become an adaptation of new habits often influence the public in viewing and determining their attitude towards social traditions that had been taking place before the pandemic era. The appeal that continues to be disseminated to the public during the pandemic will not just disappear until the pandemic ends. Then the memory of the difficulties faced also affects the community in acting in the future, the feeling of being safe and comfortable in carrying out social interactions in the community will automatically not be the same, and tends to decrease after the pandemic ends later. The social environment is certainly affected and will not be the same again.

\section{CONCLUSION}

Covid-19 pandemic has an impact on the preservation of the social environment of the people in Banjarmasin. The impact is in the form of changes to social traditions that involve physical contact. There are several traditions that have undergone a shift and there are also several traditions that have emerged in society. Various social traditions have decreased the intensity of their implementation by the community. In a survey during the pandemic the tradition that was most affected was the handshake tradition with 93 out of 100 respondents saying they no longer implement it. Then from the ten traditions mentioned, the one that shows the least impacted number is the tradition of pilgrimage to the grave and thanksgiving with the number of voters who do not perform together as many as 73 out of 100 people. In addition, a community compliance survey related to health protocols during the pandemic shows that washing hands before and after doing something is the new habit that is most obeyed by the community.

The results of the post-pandemic predictive survey show that the new habit of washing hands has decreased in the number of respondents compared to the survey during the pandemic, which from the initial number of all respondents (100 people) washing their hands to only 94 people, but this habit still shows a positive trend with a higher percentage which high enough to be maintained by the community at $94 \%$. Still regarding the prediction of people's behavior towards post-pandemic health protocols, it turns out that the habit of maintaining physical distancing is a health protocol that shows the lowest number to be maintained, there are 44 people out of 100 respondents chose not to do it anymore. This means that physical distancing behavior will be abandoned by society.

The results of the predictive survey regarding the traditions and social habits (behavior) of the people in Banjarmasin after the pandemic ends showed that the tradition that was most affected was the mewarung tradition, with 46 respondents who answered that they were no longer practicing this tradition. Meanwhile, in the other nine traditions, the majority of people will return to doing it. Because some traditions that shifted during the pandemic were related to ritual or ceremonial origins of Islamic teachings, it was very difficult for the people of Banjarmasin to leave them, so the shift was only temporary during the pandemic. If the pandemic ends one day, social traditions and behavior that breathe Islam will be carried out again.

\section{REFERENCES}

[1] Kementerian Pendidikan dan Kebudayaan, Kamus Besar Bahasa Indonesia, Jakarta [Online], 2020.2 DOI: https://kbbi.kemdikbud.go.id/

[2] Ngalim, Purwanto, Psikologi Masyarakat, PT. Remaja Rosdakarya, Bandung, 2003, Hal. 28

[3] Muhroji, dkk, Manajemen Pendidikan, Universitas Muhammadiyah Surakarta Press, Surakarta, 2011, Hal. 72

[4] Saragih, SG, Sinaga, F., Sinaga, NB Hubungan Lingkungan Sosial dengan Efektivitas Belajar Mahasiswa Sekolah Tinggi Kesehatan Santo Borromeus. Jurnal Pendidikan tentang 
Lingkungan Sosial, 2013, Hal. 2 DOI: http://www.ejournal.stikesborromeus.ac.id/jurnal .php?detail $=$ jurnal $\&$ file $=$ jurnal $\% 20$

7.pdf\&id $=495 \& \mathrm{~cd}=0 \mathrm{~b} 2173 \mathrm{ff} 6 \mathrm{ad} 6 \mathrm{a} 6 \mathrm{fb} 09 \mathrm{c} 95 \mathrm{f} 6 \mathrm{~d} 5$ 0001df6\&name= jurnal\%207.pdf

[5] ST Djajadiningrat, Pemikiran, Tantangan dan Permasalahan Lingkungan, Aksara Buana, Bandung, 2001, Hal. 101-102

[6] Gillin dan Gillin, Cultural Sociology, a Revision of An Introduction to Sociology, The Macmillan Company, New York, 1954

[7] Fakhrul, Dampak Bencana Alam Terhadap Perubahan Perilaku Sosial Masyarakat, Fakultas Dakwah Dan Komunikasi UIN Ar-Raniry, Banda Aceh, 2018

[8] Sugiyono, Metodologi Penelitian Kuantitatif, Kualitatif Dan R\&D, Alfabeta, Bandung, 2013, Hal. 11

[9] Harre dan Secord, The Explanation of Social Behaviour, Blackwell, Oxford, 1972, Hal. 17
[10] Ideham, M. Suriansyah, dkk, Sejarah Banjar, Provinsi Kalimantan Selatan, Banjarmasin 2007, Hal. 232

[11] Daud, Alfani, Islam dan Masyarakat Banjar "Deskripsi dan Analisa Kebudayaan Banjar", PT. Raja Grafindo Persada, Jakarta, 1997, Hal. 565

[12] Haq, Anwarul, Bimbingan Remaja Berakhlak Mulia "Cara Praktis Hidup Sehari-hari”, Marja, Bandun, 2004, Hal. 65

[13] Wargadinata, Wildana, Spiritual Shalawat, UIN -MALIKI Press, Malang, 2010, Hal. 55-56

[14] Mulyana, Deddy, Prinsip prinsip Dasar Komunikasi, Remaja Rosdakarya, Bandung, 2001, Hal 16

[15] Mantra. IB, Migrasi Penduduk Indonesia, PPK UGM, Yogyakarta, 1983

[16] Kuntowijoyo, Budaya dan Masyarakat, Tiara Wacana, Yogyakarta, 2006, Hal. 109 